\title{
Hubungan Antara Perilaku Keselamatan Kerja Terhadap Penggunaan Alat Pelindung Diri (APD) Pada Karyawan PT Surya Agrolika Reksa Di Sei. Basau
}

\author{
Relationship Between Work Safety Behavior of The Use Of Personal Protective Equipment \\ (PPE) in Employees of PT Surya Agrolika Reksa in Sei. Basau
}

\author{
Firman Edigan ${ }^{1, *}$, Linda Ratna Purnama Sari ${ }^{1}$, Risa Amalia $^{1}$ \\ ${ }^{1}$ Program Studi Ilmu Kesehatan Masyarakat, STIKes Hang Tuah Pekanbaru
}

\begin{abstract}
* Corresponding author : edigan@htp.ac.id
Tel.: +62-85-263-8079; fax: +62-85-263-8079

Received: Feb 1, 2019; Accepted: Mar 20, 2019

DOI: 10.25299/saintis.2019.vol19(02).3741
\end{abstract}

\section{Abstrak}

Alat Pelindung Diri (APD) merupakan seperangkat alat yang digunakan oleh tenaga kerja untuk melindungi seluruh atau sebagian tubuhnya terhadap kemungkinan adanya potensi bahaya di tempat kerja atau kecelakaan kerja. Berdasarkan dari data survei yang dilakukan kejadian kecelakaan kerja di PT. Surya Agrolika Reksa Tahun 2014-2016 mengalami peningkatan. Penelitian ini bertujuan Untuk mengetahui hubungan antara perilaku keselamatan kerja terhadap penggunaan Alat Pelindung Diri (APD) yaitu tingkat pendidikan, pengetahuan, pendidikan, sikap kerja, pelatihan K3 dan pengawasan. Jenis penelitian yang digunakan bersifat kuantitatif analitik observasional. Rancangan penelitian yang digunakan adalah cross sectional. Analisa data dilakukan secara univariat dan bivariat. Hasil penelitian ini adalah variabel yang mempunyai hubungan terhadap penggunaan APD yaitu tingkat pendidikan ( $\mathrm{p}$-value=0,030), pengetahuan ( $p$-value $=0,003)$, sikap kerja ( $p$-value $=0)$, pelatihan K3 ( $\mathrm{p}$-value $=0,004)$, dan pengawasan $(\mathrm{p}$-value $=0,015)$. Kesimpulan dalam penelitian ini adalah terdapat hubungan yang signifikan antara perilaku keselamatan kerja terhadap penggunaan APD. Disarankan memberikan penyuluhan tentang perilaku keselamatan kerja dalam penggunaan APD yang baik dan benar,menganjurkan kepada karyawan di PT. Surya Agrolika Reksa untuk selalu menggunakan APD pada saat bekerja.

Kata Kunci: $A P D$, tingkat pendidikan, pengetahuan, sikap kerja, pelatihan K3 dan pengawasan

\begin{abstract}
Personal Protective Equipment (PPE) is a set of an instrument used by labour To protect all or part of his body to the predictable the potential danger in the workplace or work accident. Based on from the data the survey scene of an accident work in PT Surya agrolikareksa years 2014-2016 increased.ResearchThis aims to understand the relationship between behavior occupational safety on the use of PersonalProtective Equipment (PPE). Namely the levels of education, knowledge, education, attitude work, training occupational health and safety and supervision. The kind of research used is quantitative analytic observational. Design research used is the cross sectional. Data analysis be done in univariat and bivariate. The result of this research is the variable who are related on the use of apd namely the levels of education ( $p$-value $=0,030)$, knowledge ( $p$-value $=0,003)$, attitude work $(p$-value $=0,00)$, training occupational health and safety ( $p$-value= 0,004 ) and supervision ( $p$-value=0,001). Conclusion in this research is that there a significant relation exists between behavior occupational safety on the use of apd. Suggested expain behavior occupational safety In the use of apd good and right and suggested employees in PT Surya agrolikareksa to always use PPE in while working.
\end{abstract}

Keywords: PPE, the level of education, knowledge, attitude work, training of OSH and supervision

\section{PENDAHULUAN}

Keselamatan dan kesehatan kerja merupakan suatu pemikiran dan upaya untuk menjamin keutuhan dan kesempurnaan baik jasmani maupun rohani pekerja. Dengan keselamatan dan kesehatan kerja maka para pihak diharapkan dapat melakukan pekerjaan dengan aman dan nyaman. Pekerjaan dikatakan aman jika apapun yang dilakukan oleh pekerja tersebut, risiko yang mungkin muncul dapat dihindari [1].
Alat Pelindung Diri (APD) merupakan seperangkat alat yang digunakan oleh tenaga kerja untuk melindungi seluruh atau sebagian tubuhnya terhadap kemungkinan adanya potensi bahaya di tempat kerja atau kecelakaan kerja. APD juga merupakan kelengkapan yang wajib digunakan saat bekerja sesuai bahaya dan risiko kerja untuk menjaga keselamatan pekerja itu sendiri dan orang di sekelilingnya. APD dipakai setelah usaha rekayasa dan cara kerja yang aman APD yang dipakai memenuhi syarat enak dipakai, 
memberikan perlindungan efektif terhadap bahaya [2].

Keselamatan Kerja tertuang pada UndangUndang No. 1 Tahun 1970 yaitu bahwa setiap tenaga kerja berhak mendapat perlindungan atas keselamatan dalam melakukan pekerjaan dan orang lain yang berada di tempat kerja terjamin pula keselamatannya. Keselamatan dan kesehatan kerja mengandung nilai perlindungan tenaga kerja dari kecelakaan atau penyakit akibat kerja.Kecelakaan kerja juga dapat mempengaruhi produktivitas perusahaan. Sedangkan peraturan perundangan yang menyangkut penggunaan APD terdapat pada pasal 12 dan 13 tentang Kewajiban dan Hak Pekerja [3].

Angka kecelakaan kerja di Indonesia tahun 2011 masih dinilai tinggi dari 96.400 kecelakaan kerja yang terjadi, sebanyak 2.144 diantaranya tercatat meninggal dunia dan 42 lainnya cacat. Sampai dengan September 2012 angka kecelakaan kerja yaitu pada kisaran 80.000 kasus kecelakaan kerja. Mengutip data Badan Penyelenggara Jaminan Sosial (BPJS) Ketenagakerjaan, hingga akhir 2015 telah terjadi kecelakaan kerja sebanyak 105.182 kasus sedangkan kasus kecelakaan berat yang mengakibatkan kematian tercatat sebanyak 2.375 kasus dari total jumlah kecelakaan kerja di Indonesia.

PT Surya Agrolika Reksa merupakan salah satu perusahaan perkebunan kelapa sawit yang mengelola agro industri pabrik kelapa sawit (PKS) yang unggul, tangguh, serta mampu tumbuh dan berkembang dalam persaingan global secara berkelanjutan yang memberikan kontribusi positif kepada masyarakat sekitar perusahaan. Perusahaan mendirikan pabrik kelapa sawit (PKS) pada tahun 2001 dengan kapasitas pengolahan 60 ton/jam, pabrik dibangun di daerah jauh dari pemukiman penduduk dengan batas kebun kelapa sawit. Hal ini bertujuan untuk menghindari adanya dampak negatif yang mungkin terjadi dari kegiatan pabrik. Namun masih seringnya terjadi kecelakaan kerja di PT tersebut, salah satu faktor terjadi kecelakaan kerja yaitu kurangnya perilaku disiplin pekerja dalam penggunaan APD.

Berdasarkan dari data survei yang dilakukan kejadian kecelakaan kerja di PT Surya Agrolika Reksa dari tahun 2014 - 2016 mengalami peningkatan. Pada tahun 2015 kejadian kecelakaan kerja di bagian operator Boiler saat melakukan Pembersihan Diarea Conveyor Pembuangan Fibre, terdapat 1 kasus dari total 7 kasus kecelakaan kerja di PT Surya Agrolika Reksa, kemudian pada tahun 2016 meningkat menjadi 2 kasus dari total 5 kasus kecelakaaan. Pada tahun 2016 meningkat lagi menjadi 3 kasus dari total 6 kasus. Setelah dilakukan investigasi tim K3 PT Surya Agrolika Reksa diketahui bahwa salah satu faktor dari setiap kasus kecelakaan kerja yang terjadi di PT Surya Agrolika Reksa adalah karena tidak menggunakan Alat Pelindung Diri (APD) dengan baik dan kurangnya disiplin pekerja dalam penggunaan APD yang sudah disediakan pihak perusahaan, dimana tujuan dari penggunaan APD adalah untuk mengurangi tingkat keparahan kecelakaan pekerja pada saat bekerja.

Berdasarkan uraian di atas, peneliti tertarik untuk melakukan penelitian mengenai "Hubungan antara Perilaku Keselamatan Kerja Terhadap Penggunaan Alat Pelindung Diri (APD) pada Karyawan PT Surya Agrolika Reksa di Sei. Basau". Tujuan dari penelitian ini adalah untuk mengetahui hubungan antara perilaku keselamatan kerja terhadap penggunaan Alat Pelindung Diri (APD) pada karyawan PT Surya Agrolika Reksa di Sei. Basau.

\section{Tujuan Penelitian}

\section{Tujuan Umum}

Untuk mengetahui hubungan antara perilaku keselamatan kerja terhadap penggunaan Alat Pelindung Diri (APD) pada karyawan PT Surya Agrolika Reksa di Sei. Basau.

\section{Tujuan Khusus}

Diketahuinya hubungan antara tingkat pendidikan terhadap penggunaan APD pada karyawan PT Surya Agrolika Reksa di Sei. Basau. Kemudian Diketahuinya hubungan antara pengetahuan terhadap penggunaan APD pada karyawan PT Surya Agrolika Reksa di Sei. Basau. Demikian juga diketahuinya hubungan antara sikap kerja terhadap penggunaan APD pada karyawan PT Surya Agrolika Reksa di Sei. Basau. Untuk melihat hubungan antara pelatihan K3 terhadap penggunaan APD pada karyawan PT Surya Agrolika Reksa di Sei. Basau. Serta mengetahui hubungan antara pengawasan terhadap penggunaan APD pada karyawan PT Surya Agrolika Reksa di Sei. Basau.

\section{METODOLOGI}

Kerangka teori penelitian sebagai berikut :

Sumber: Lawrence Green dalam (4)

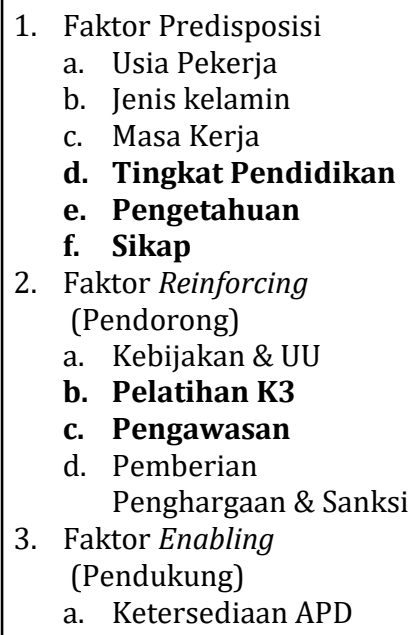

2. Faktor Reinforcing (Pendorong) 
Gambar 1. Kerangka Teori Penelitian dirumuskanlah kerangka konsep yang dapat dilihat pada gambar 2 berikut:

\section{Variabel Independen Variabel Dependen}

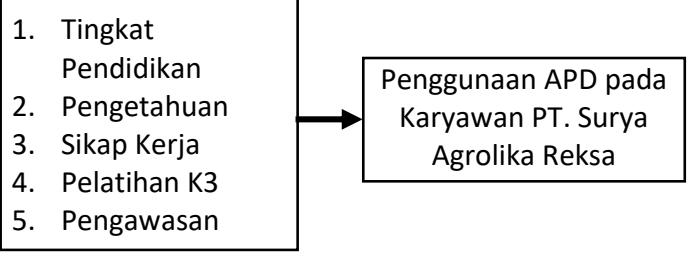

Gambar 2. Kerangka Konsep Penelitian

Jenis penelitian yang digunakan adalah penelitian analitik observasional dengan pendekatan kuantitatif. Desain penelitian ini menggunakan desain cross sectional study, yaitu menghubungkan variabel bebas (tingkat pendidikan, pengetahuan, sikap kerja, pelatihan K3, dan pengawasan) dengan variabel terikat (penggunaan APD) secara bersamaan pada waktu tertentu dalam suatu sampel populasi.Penelitian ini dilakukan di PT Surya Agrolika Reksa di Sei. Basau. Populasi dalam penelitian ini adalah seluruh Karyawan bagian pengolahan PT Surya Agrolika Reksa di Sei. Basau yang berjumlah 108 orang dengan sampel berjumlah 66 responden.
Berdasarkan kerangka teori diatas maka

Besar sampel pada penelitian ini ditetapkan berdasarkan rumus issac dan Michael adalah sebagai berikut:

$$
\begin{aligned}
& \mathrm{S}=\frac{\mathrm{N} \cdot Z^{2} 1-\alpha / 2 \cdot P(1-P)}{(N-1) \cdot \mathrm{d}^{2}+Z^{2} 1-\alpha / 2 \cdot P(1-P)} \\
& \mathrm{n}=65,51 \approx 66
\end{aligned}
$$

Jadi jumlah sampel dalam penelitian ini sebanyak 66 responden.

Teknik pengambilan sampel dalam penelitian ini menggunakan teknik simple random sampling yaitu pengambilan sampel dilakukan secara random atau acak sehingga mempunyai kesempatan yang sama dan bebas dipilih sebagai sampel [4].

Penelitian ini dilakukan di pekerja PT Surya Agrolika Reksa di Sei. Basau yang berjumlah 66 orang, dengan kriteria sebagai berikut:

Kriteria Inklusi

Karyawan bersedia menjadi responden. Karyawan yang mampu berkomunikasi dengan baik.

Kriteria Eksklusi

Karyawan yang tidak hadir/ sakit/sedang cuti.

\section{Variabel Penelitian \& Definisi Operasional}

Variabel penelitian dan definisi operasional

\begin{tabular}{|c|c|c|c|c|c|c|}
\hline No. & Keterangan & Definisi Operasional & $\begin{array}{l}\text { Alat } \\
\text { Ukur }\end{array}$ & $\begin{array}{l}\text { Cara } \\
\text { Ukur }\end{array}$ & $\begin{array}{l}\text { Skala } \\
\text { Ukur }\end{array}$ & $\begin{array}{l}\text { Hasil } \\
\text { Ukur }\end{array}$ \\
\hline A. & \multicolumn{6}{|c|}{ Variabel Dependen } \\
\hline 1. & $\begin{array}{l}\text { Penggunaan } \\
\text { APD }\end{array}$ & $\begin{array}{l}\text { Wujud seorang Pekerja } \\
\text { menggunakan APD pada } \\
\text { saat bekerja }\end{array}$ & Kuesioner & Observasi & Ordinal & $\begin{array}{l}0=\text { Tidak, } \\
\text { jika tidak } \\
\text { menggunakan } \\
\text { APD } \\
1=\text { Ya, } \\
\text { jika } \\
\text { menggunakan } \\
\text { APD }\end{array}$ \\
\hline B. & \multicolumn{6}{|c|}{ Variabel Independen } \\
\hline 1 & $\begin{array}{l}\text { Tingkat } \\
\text { Pendidikan }\end{array}$ & $\begin{array}{l}\text { Jenjang pendidikan formal } \\
\text { terakhir yang pernah } \\
\text { dicapai oleh pekerja }\end{array}$ & Kuesioner & Wawancara & Ordinal & $\begin{array}{l}0=\text { Rendah } \\
1=\text { Tinggi }\end{array}$ \\
\hline 2 & Pengetahuan & $\begin{array}{l}\text { Semua informasi tentang } \\
\text { APD yang diketahui dan } \\
\text { dimengerti oleh Pekerja }\end{array}$ & Kuesioner & Wawancara & Ordinal & $\begin{array}{l}0=\text { Buruk } \\
1=\text { Baik }\end{array}$ \\
\hline 3 & Sikap Kerja & $\begin{array}{l}\text { Respon tertutup pekerja } \\
\text { terhadap penggunaan APD }\end{array}$ & Kuesioner & Wawancara & Ordinal & $\begin{array}{l}0=\text { Negatif } \\
1=\text { Positif }\end{array}$ \\
\hline 4 & Pelatihan K3 & $\begin{array}{lr}\text { Kegiatan } & \text { pemberian } \\
\text { informasi } & \text { terkait } \\
\text { penggunaan APD } & \end{array}$ & Kuesioner & Wawancara & Ordinal & $\begin{array}{l}0=\text { Tidak Pernah } \\
1=\text { Pernah }\end{array}$ \\
\hline 5 & Pengawasan & $\begin{array}{l}\text { Usaha penegakan peraturan } \\
\text { yang harus dipatuhi oleh } \\
\text { pekerja dalam penggunaan } \\
\text { APD }\end{array}$ & Kuesioner & Wawancara & Ordinal & $\begin{array}{l}0=\text { Tidak Ada } \\
1=\text { Ada }\end{array}$ \\
\hline
\end{tabular}
penelitian adalah sesuai Tabel 1. berikut:

Tabel 1. Variabel Penelitian dan Definisi Operasional 


\section{Teknik Pengumpulan Data}

Jenis data yang digunakan dalam penelitian ini adalah:

1. Data Primer

Data primer yaitu data yang diambil secara langsung dan bersumber dari sampel yang dikumpulkan dengan cara wawancara menggunakan kuesioner meliputi data identitas responden, Pengetahuan, Pendidikan, Pelatihan, Ketersediaan APD dan pengawasan. Kuesioner ini di adopsi dari penelitian [5].

\section{Data Sekunder}

Data sekunder adalah data yang tersusun dalam bantuk data yang telah dikumpulkan. Data sekunder diperoleh dari perusahaan tempat penelitian yaitu PT Surya Agrolika Reksa di Sei. Basau mengenai profil perusahaan, jumlah pekerja dan data kecelakaan kerja serta beberapa jurnal yang diperoleh dari internet.

\section{Pengolahan Data}

Data yang diperoleh akan diolah dengan tahap - tahap sebagai berikut :

\section{Editing}

Merupakan kegiatan untu melakukan pengecekan data sekunder, apakah data sudah lengkap (semua isian sudah terisi), jelas (apakah tulisannya cukup jelas terbaca), relevan (apakah data sesuai dengan hasil pengukuran) dan konsisten.

\section{Coding}

Merupakan kegiatan mengubah data berbentuk huruf menjadi data berbentuk huruf menjadi data berbentuk angka atau bilangan. Pengkodean data ini bertujuan untuk mengklasifikasi data jawaban dari masing-masing pertanyaan dengan kode sehingga mempercepat dan mempermudah proses entri data serta mempermudah proses pengolahan dan analisis data.

3. Entry

Setelah dilakukan pengecekan dan pengkodean, maka langkah selanjutnya adalah memproses data agar data yang sudah dientri dapat dianalisis. Pemrosesan data dilakukan dengan mengentri data ke paket program komputer.

\section{Procesing Data}

Pada tahapan ini, peneliti melakukan proses untuk menganalisis data sesuai dengan analisis yang digunakan dalam penelitian ini yaitu univariat dan bivariat.

\section{Analisis Data}

Data yang diperoleh dimasukkan kedalam program data dengan menggunakan berbantuan Program Komputer. Data yang diperoleh dari jawaban atau isian kuesioner yang telah diperoleh dari responden akan diolah dan dihitung dengan menggunakan Software Microsoft Office Excel dan Statistical Package for the Social Sciences (SPSS). Data di analisis dengan dua cara, yaitu:

1. Analisis Univariat

Analisis univariat dilakukan untuk mendiskripsikan distribusi frekuensi pada variabel yang diteliti. Hasil analisis univariat akan ditampilkan dalam bentuk tabel dan narasi.

2. Analisis Bivariat

Analisis bivariat dimaksudkan untuk mengetahui hubungan antara variabel independen dengan variabel dependen. Analisis bivariat dilakukan dengan menggunakan uji chi square $\left(\mathrm{x}^{2}\right)$ dengan tingkat kepercayaan $95 \%$ dan $\alpha=0,05$.

\section{HASIL DAN PEMBAHASAN}

\section{HASIL}

\section{Analisis Univariat}

Berdasarkan hasil wawancara dengan responden tentang hubungan perilaku keselamatan kerja terhadap penggunaan APD pada karyawan PT Surya Agrolika Reksa yang didapatkan hasil sebagai berikut:

Tabel 2. Distribusi Frekuensi Responden pada Karyawan PT Surya Agrolika Reksa di Sei Basau

\begin{tabular}{|c|c|c|c|c|}
\hline No & Variabel & Kategori & Jlh & $\begin{array}{c}\text { Persenta } \\
\text { se } \\
(\%) \\
\end{array}$ \\
\hline 1 & $\begin{array}{l}\text { Dependen } \\
\text { Penggunaan } \\
\text { APD }\end{array}$ & $\begin{array}{l}\text { Tidak APD } \\
\text { APD }\end{array}$ & $\begin{array}{l}39 \\
27\end{array}$ & $\begin{array}{l}59,1 \\
40,9\end{array}$ \\
\hline 2 & $\begin{array}{l}\text { Independen } \\
\text { a. Tingkat } \\
\text { Pendidikan } \\
\text { b. Pengetahu } \\
\quad \text { an }\end{array}$ & $\begin{array}{l}\text { Rendah } \\
\text { Tinggi } \\
\text { Buruk } \\
\text { Baik }\end{array}$ & $\begin{array}{l}18 \\
48 \\
\\
28 \\
38\end{array}$ & $\begin{array}{r}27,3 \\
72,7 \\
42,4 \\
57,6 \\
\\
56,1 \\
43,9\end{array}$ \\
\hline & $\begin{array}{l}\text { d. Pelatihan } \\
\text { K3 }\end{array}$ & $\begin{array}{l}\text { Tidak } \\
\text { Pernah } \\
\text { Pernah }\end{array}$ & $\begin{array}{l}35 \\
31\end{array}$ & $\begin{array}{l}53,0 \\
47,0\end{array}$ \\
\hline & $\begin{array}{l}\text { e. Pengawas } \\
\mathrm{An}\end{array}$ & $\begin{array}{l}\text { Tidak Ada } \\
\text { Ada }\end{array}$ & $\begin{array}{l}42 \\
24\end{array}$ & $\begin{array}{l}63,6 \\
36,4\end{array}$ \\
\hline
\end{tabular}

Berdasarkan Tabel 2 di atas, bahwa responden yang menggunakan APD sebanyak 39 responden $(59,1 \%)$, responden dengan tingkat pendidikan tinggi sebanyak 48 responden $(72,7 \%)$, responden dengan pengetahuan baik sebanyak 38 responden (57,6\%), responden yang sikap kerja negatif sebanyak 37 responden $(56,1 \%)$, responden yang tidak pernah mengikuti pelatihan K3 
sebanyak 35 responden (53,0\%), dan responden yang tidak ada pengawasan sebanyak 42 responden $(63,6 \%)$.

\section{Analisis Bivariat}

Hasil uji bivariat terhadap 5 variabel yang mempunyai hubungan signifikan dengan penggunaan APD pada karyawan PT Surya Agrolika Reksa di Sei Basauyaitu Tingkat Pendidikanp-value $=0,003(<0,05)$, pengetahuan $p$-value $=0,003(<0,05)$, Sikap Kerja $p$-value $=0,003(<0,05)$, Pelatihan K3 $p$ value $=0,004(<0,05)$, pengawasan $p$-value $=$ $0,015(<0,05)$.

Dari analisa POR, responden yang tingkat pendidikan rendah 5 kali berisiko dari yang tidak menggunakan APD, dibandingkan responden yang tingkat pendidikannya tinggi. Responden dengan pengetahuan buruk 6 kali berisiko tidak menggunakan APD dibandingkan responden dengan pengetahuan baik. Responden yang mempunyai sikap negatif berisiko 9,5 kali tidak menggunakan APD dibandingkan responden yang mempunyai sikap positif. Responden yang tidak pernah mengikuti pelatihan K3 5,3 kali berisiko tidak menggunakan APD dibandingkan responden yang pernah mengikuti pelatihan K3 dan responden yang tidak ada pengawasan 4,16 kali berisiko tidak menggunakan APD dibandingkan responden yang ada pengawasannya.

\section{Hubungan Tingkat Pendidikan terhadap Penggunaan APD}

Hasil uji statistik untuk melihat hubungan tingkat pendidikan terhadap penggunaan APD dapat dilihat pada Tabel 3 . beriukut:

Tabel 3. Hubungan Tingkat Pendidikan terhadap penggunaan APD pada Karyawan PT Surya Agrolika Reksa di Sei Basau

\begin{tabular}{|c|c|c|c|c|c|c|c|c|}
\hline \multirow{3}{*}{$\begin{array}{c}\text { Tingkat } \\
\text { Pendidikan }\end{array}$} & \multicolumn{4}{|c|}{ Penggunaan APD } & \multirow{2}{*}{\multicolumn{2}{|c|}{ Total }} & \multirow[t]{3}{*}{ P Value } & \multirow{3}{*}{$\begin{array}{l}\text { POR } \\
\text { CI (95\%) }\end{array}$} \\
\hline & \multicolumn{2}{|c|}{ Tidak } & \multicolumn{2}{|c|}{ Ya } & & & & \\
\hline & $\bar{n}$ & $\%$ & $\mathbf{n}$ & $\%$ & $\bar{n}$ & $\%$ & & \\
\hline Rendah & 15 & 83,3 & 3 & 16,7 & 18 & 100 & 0,003 & 5,00 \\
\hline Tinggi & 24 & 50 & 24 & 50 & 48 & 100 & & $(1,28-19,53)$ \\
\hline Total & 39 & 59,1 & 27 & 40,9 & 66 & 100 & & \\
\hline
\end{tabular}

Berdasarkan Tabel 3, menunjukkan bahwa dari 66 responden yang tingkat pendidikan rendah sebanyak 15 orang $(83,3 \%)$ yang tidak menggunakan APD. Hasil uji ChiSquare didapatkan nilai $p$-value $=0,003(<0,05)$ serta didapat nilai $\mathrm{OR}=5,00$ dengan (CI 95\%; 1,28-19,53) yang artinya responden yang tingkat pendidikan rendah 5 kali berisiko tidak menggunakan APD, dibandingkan responden yang tingkat pendidikannya tinggi.

Tabel 4. Hubungan Pengetahuan terhadap penggunaan APD pada Karyawan PT Surya Agrolika Reksa di Sei Basau

\begin{tabular}{|c|c|c|c|c|c|c|c|c|}
\hline \multirow[t]{3}{*}{ Pengetahuan } & \multicolumn{4}{|c|}{ Penggunaan APD } & \multirow{2}{*}{\multicolumn{2}{|c|}{ Total }} & \multirow[t]{3}{*}{ P Value } & \multirow{3}{*}{$\begin{array}{c}\text { POR } \\
\text { CI }(95 \%)\end{array}$} \\
\hline & \multicolumn{2}{|c|}{ Tidak } & \multicolumn{2}{|c|}{ Ya } & & & & \\
\hline & $\mathbf{n}$ & $\%$ & $\mathbf{n}$ & $\%$ & $\mathbf{N}$ & $\%$ & & \\
\hline Buruk & 23 & 82,1 & 5 & 17,9 & 28 & 100 & 0,003 & 6,32 \\
\hline Baik & 16 & 42,1 & 22 & 57,9 & 38 & 100 & & $(1,97-20,21)$ \\
\hline Total & 39 & 59,1 & 27 & 40,9 & 66 & 100 & & \\
\hline
\end{tabular}

Berdasarkan Tabel 4, menunjukkan bahwa dari 66 responden yang pengetahuan buruk sebanyak 23 orang $(82,1 \%)$ sedangkan responden yang pengetahuan baik sebanyak 16 orang $(42,1 \%)$. Hasil uji Chi-Square didapatkan nilai $p$-value $=0,003(<0,05)$ serta didapat nilai $\mathrm{OR}=6,32 \quad(\mathrm{CI} \quad 95 \% ; 1,97-20,21)$ berarti responden dengan pengetahuan buruk 6 kali

\section{Hubungan Pengetahuan terhadap Penggunaan APD}

Hasil uji statistik untuk melihat hubungan antara pengetahuan terhadap penggunaan APD dapat dilihat pada Tabel 4 . berikut: 
Tabel 5. Hubungan Sikap Kerjaterhadap Penggunaan APDpada Karyawan

PT Surya Agrolika Reksa di Sei Basau

\begin{tabular}{|c|c|c|c|c|c|c|c|c|}
\hline \multirow[t]{3}{*}{ Sikap Kerja } & \multicolumn{4}{|c|}{ Penggunaan APD } & \multirow{2}{*}{\multicolumn{2}{|c|}{ Total }} & \multirow[t]{3}{*}{ P Value } & \multirow{3}{*}{$\begin{array}{c}\text { POR } \\
\text { CI }(95 \%)\end{array}$} \\
\hline & \multicolumn{2}{|c|}{ Tidak } & \multicolumn{2}{|c|}{$\mathbf{Y a}$} & & & & \\
\hline & $\mathbf{n}$ & $\%$ & $\mathbf{n}$ & $\%$ & $\mathbf{N}$ & $\%$ & & \\
\hline Negatif & 30 & 81,1 & 7 & 18,9 & 37 & 100 & 0,000 & 9,524 \\
\hline Positif & 9 & 31 & 20 & 69 & 29 & 100 & & $(3,051-29,728)$ \\
\hline$\overline{\text { Total }}$ & 39 & 59,1 & 27 & 40,9 & 66 & 100 & & \\
\hline
\end{tabular}

Berdasarkan Tabel 5, menunjukkan bahwa dari 66 responden, yang sikap negatif sebanyak 30 orang $(81,1 \%)$ yang tidak menggunakan APD, sedangkan yang sikap positif sebanyak 9 orang (31\%). Hasil uji ChiSquare didapatkan nilai $p$-value $=0,000(<0,05)$ terdapat hubungan yang signifikan. Dengan nilai OR= 9,524 (CI 95\%; 3,051-29,728) artinya responden yangmempunyai sikap negatif berisiko 9,5 kali tidak menggunakan APD dibandingkan responden yang mempunyai sikap positif.

\section{Hubungan Pelatihan K3 terhadap Penggunaan APD}

Hasil uji statistik untuk melihat hubungan antara pelatihan K3 terhadap penggunaan APD dapat dilihat pada Tabel 6 . berikut:

Tabel 6. Hubungan Pelatihan K3 terhadap penggunaan APD pada Karyawan

PT Surya Agrolika Reksa di Sei Basau

\begin{tabular}{|c|c|c|c|c|c|c|c|c|}
\hline \multirow[t]{3}{*}{ Pelatihan K3 } & \multicolumn{4}{|c|}{ Penggunaan APD } & \multirow{2}{*}{\multicolumn{2}{|c|}{ Total }} & \multirow[t]{3}{*}{ P Value } & \multirow{3}{*}{$\begin{array}{c}\text { POR } \\
\text { CI }(95 \%)\end{array}$} \\
\hline & \multicolumn{2}{|c|}{ Tidak } & \multicolumn{2}{|c|}{ Ya } & & & & \\
\hline & $\bar{n}$ & $\%$ & $\mathbf{n}$ & $\%$ & $\mathbf{N}$ & $\%$ & & \\
\hline Tidak Pernah & 27 & 77,1 & 8 & 22,9 & 35 & 100 & 0,004 & 5,34 \\
\hline Pernah & 12 & 38,7 & 19 & 61,3 & 31 & 100 & & $(1,833-15,578)$ \\
\hline Total & 39 & 59,1 & 27 & 40,9 & 66 & 100 & & \\
\hline
\end{tabular}

Berdasarkan Tabel 6, menunjukkan bahwa dari 66 responden, sebanyak 27 orang $(77,1 \%)$ tidak pernah mengikuti pelatihan K3 sedangkan yang pernah sebanyak 12 orang $(38,7 \%)$. Hasil uji Chi-Square didapatkan nilai $p$ value $=0,004(<0,05)$ serta didapat nilai POR= 5,34 (CI 95\%; 1,833-15,578) artinya responden yang tidak pernah mengikuti pelatihan K3 5,3 kali berisiko tidak menggunakan APD dibandingkan responden yang pernah mengikuti pelatihan K3.

\section{Hubungan Pengawasan terhadap Penggunaan APD}

Hasil uji statistik untuk melihat hubungan antara pengawasan terhadap penggunaan APD dapat dilihat pada Tabel 7 . berikut:

Tabel 7. Hubungan Pengawasan terhadap penggunaan APD pada Karyawan

PT Surya Agrolika Reksa di Sei Basau

\begin{tabular}{|c|c|c|c|c|c|c|c|c|}
\hline \multirow[t]{3}{*}{ Pengawasan } & \multicolumn{4}{|c|}{ Penggunaan APD } & \multirow{2}{*}{\multicolumn{2}{|c|}{ Total }} & \multirow[t]{3}{*}{ P Value } & \multirow{3}{*}{$\begin{array}{c}\text { POR } \\
\text { CI }(95 \%)\end{array}$} \\
\hline & \multicolumn{2}{|c|}{ Tidak } & \multicolumn{2}{|c|}{ Ya } & & & & \\
\hline & $\mathbf{n}$ & $\%$ & $\mathbf{n}$ & $\%$ & $\mathbf{N}$ & $\%$ & & \\
\hline Tidak Ada & 30 & 71,4 & 12 & 28,6 & 42 & 100 & 0,015 & 4,167 \\
\hline Ada & 9 & 37,5 & 15 & 62,5 & 24 & 100 & & $(1,438-12,069)$ \\
\hline Total & 39 & 59,1 & 27 & 40,9 & 66 & 100 & & \\
\hline
\end{tabular}

Berdasarkan Tabel 7, menunjukkan bahwa dari 66 responden, yang tidak adanya pengawasan sebanyak 30 orang $(71,4 \%)$ sedangkan responden yang ada pengawasan sebanyak 9 orang $(37,5 \%)$ yang tidak menggunakan APD. Hasil uji Chi-Square didapatkan nilai $p$-value $=0,015(<0,05)$ serta didapat nilai OR=4,167 (CI 95\%;1,438-12,069) artinya responden yang tidak ada pengawasan 
4,16 kali berisiko dibandingkan responden yang ada pengawasannya.

\section{PEMBAHASAN}

\section{Hubungan Tingkat Pendidikan terhadap Penggunaan APD}

Dari hasil Uji Statistik diperoleh nilai $p$ value $=0,030$ artinya terdapat hubungan yang signifikan antara tingkat pendidikan terhadap penggunaan APD pada Karyawan PT Surya Agrolika Reksa di Sei Basau. Nilai OR= 5,0(CI 95\%; 1,28-19,53) yang artinya responden yang tingkat pendidikan rendah 5 kali lebih beresiko tidak menggunakan APD dibandingkan dengan yang tingkat pendidikan tinggi. Karena tingkat pendidikan tinggi sangat berpengaruh terhadap penggunaan APD, Dan berdasarkan hasil penelitian yang dilakukan tingkat pendidikan masih sangat rendah.

Menurut teori bahwa tingkat pendidikan ini erat kaitannya dengan pengetahuan yang dimiliki oleh masing-masing pekerja karena semakin tinggi tingkat pendidikan formal seseorang, maka semakin banyak pula pengetahuan yang didapat dan dipelajari oleh orang tersebut [6].

Dari hasil penelitian yang dilakukan peneliti menunjukkan bahwa hasil penelitian yang dilakukan peneliti, senada dan berkolerasi dengan yang diungkapkan dalam teori yang disampaikan ahli. Berdasarkan hasil penelitian, bahwa ada hubungan tingkat pendidikan terhadap penggunaan APD. Apabila seseorang dengan tingkat pendidikan yang tinggi maka seseorang tersebut memiliki pengetahuan yang lebih sehingga cenderung berperilaku yang baik contohnya dalam penggunaan APD untuk mencegah terjadinya kecelakaan kerja.

\section{Hubungan Pengetahuan terhadap Penggunaan APD}

Dari hasil Uji Statistik diperoleh nilai $p$ value $=0,003$ artinya terdapat hubungan yang signifikan antara pengetahuan terhadap penggunaan APD pada Karyawan PT Surya Agrolika Reksa di Sei Basau. Nilai OR didapatkan 6,32(CI 95\%;1,979-20,215) artinya responden dengan pengetahuan buruk 6,32 kali lebih beresiko tidak menggunakan APD dibandingkan responden yang pengetahuan baik.Karena Pengetahuan sangat berpengaruh untuk meningkatkan kualitas penggunaan APD.

Hasil penelitian ini sesuai dengan teori yang dikemukakan oleh Notoadmodjo, dimana pengetahuan adalah hasil penginderaan manusia, atau hasil tahu seseorang terhadap terhadap objek melalui indera yang dimilikinya (mata, hidung, telinga, dan sebagainya). Dengan sendirinya pada waktu penginderaan sehingga menghasilkan pengetahuan tersebut sangat dipengaruhi oleh intensitas perhatian dan persepsi terhadap objek. Sebagian besar pengetahuan seseorang diperoleh melalui indera pendengaran (telinga), dan indera penglihatan (mata) [6].

Pengetahuan merupakan hasil dari tahu dan ini terjadi setelah seseorang melakukan penginderaan terhadap suatu objek tertentu. Penginderaan terjadi melalui panca indera manusia yaitu indera penglihatan, pendengaran, penciuman, rasa dan raba. Menrut peneliti bahwa, perilaku apabila didasari oleh pengetahuan kesadaran dan sikap positif maka perilaku tersebut akan lebih baik dibandingkan jika tidak didasari oleh pengetahuan, kesadaran dan sikap positif maka akan memberikan hubungan positif yang berbanding lurus. Dalam penelitian di PT Surya Agrolika Reksa di Sei Basau mempertegas bahwa terdapat hubungan yang signifikan antara pengetahuan terhadap penggunaan APD.

$\begin{array}{ccc}\text { Menurut } & \text { peneliti, semakin baik } \\ \text { pengetahuan seorang pekerja maka }\end{array}$ perilakunyayang didasari oleh pengetahuan tersebut akan baik pula dalam mematuhi akan pentingnya penggunaan APD untuk menjaga keselamatan dan kesehatan dalam bekerja, demikian juga dengan kondisi sebaliknya.

Hasil penelitian ini sejalan dengan penelitian [7], diketahui bahwa ada hubungan pengetahuan dengan penggunaan alat pelindung diri (APD) dengan nilai $p$-value = 0,001 .

Berbeda dengan penelitian peneliti sebelumnya, yang dilaksanakan pada PT PLN Rayon Tembilahan, menunujukkan bahwa tidak terdapat hubungan antara pengetahuan dengan penggunan APD pada pekerja teknisi mesin di PT PLN Rayon tembilan tahun 2017 (Pvalue $=0,899 . \mathrm{OR}=1.375, \mathrm{Cl} 95 \%=0.361$ 5.240) dengan 16 responden berpengetahuan baik dan 19 berpengetahuan kurang baik.

Berdasarkan hasil penelitian di PT Surya Agrolika Reksa di Sei Basau, bahwa ada hubungan pengetahuan yang baik terdapat 39 responden, dan hubungan pengetahuan yang tidak baik terdapat 27 responden, memperlihatkan hubungan positif antara pengetahuan dengan penggunaan APD. Dimana pengetahuan berpengaruh terhadap perilaku, jika pengetahuan seseorang tinggi maka perilaku cenderung kearah yang baik sehingga tahu tentang pentingnya tujuan dari penggunaan APD bagi dirinya. 


\section{Hubungan Sikap Kerja terhadap Penggunaan APD}

Hasil penelitian menunjukkan bahwa nilai $P$-value $=0,000$ artinya terdapat hubungan yang signifikan antara sikap kerja terhadap penggunaan APD pada Karyawan PT Surya Agrolika Reksa di Sei Basau padaTahun 2017 dengan nilai OR=9,524 (CI95\%; 3,051-29,728) artinya responden dengan sikap negatif 9,5 kali lebih beresiko tidak menggunakan APD dibandingkan responden yang sikap positif.Karena sikap kerja yang tidak baik sangat berpengaruh kepada pengetahuan yang rendah.

Menurut teori, sikap adalah reaksi atau respons yang masih tertutup dari seseorang terhadap stimulus atau objek.Manifestasi dari sikap tidak dapat langsung dilihat tetapi hanya dapat ditafsirkan terlebih dahulu dari perilaku yang tertutup [6]. Sikap secara nyata menunjukkan konotasi adanya kesesuaian reaksi terhadap stimulus tertentu. Sikap merupakan suatu tindakan atau aktifitas, akan tetapi merupakan predisposisi tindakan dan perilaku. Sikap penggunaan APD merupakan tanggapan atau respon pekerja terhadap pemakaian APD pada waktu bekerja.

Sementara menurut [8], Sikap adalah suatu reaksi tertutup dari seseorang terhadap suatu stimulus atau objek. Sikap seseorang bisa dipengaruhi oleh prilaku dan individu tersebut, sikap merupakan suatu kecendrungan untuk bertindak terhadap suatu objek, dengan suatu cara dengan menyatakan adanya tanda-tanda untuk menyenangi atau tidak menyenangi suatu objek tersebut.

Berdasarkan penelitian di PT Surya Agrolika Reksa di Sei Basau telah dilakukan, bahwa sikap kerja pekerja yang negatif terdapat 33 responden, dan yang positif sebanyak 29 responden.Hal ini dapat terlihat dari hasil dan pengolahan data penelitian diketahui dari hasil di lapangan bahwa responden masih banyak yang tidak menggunakan APD dengan alasan malas, lupa, lalai dan merasa ketidaknyamanan dalam mengunakan APD saat sedang bekerja. Hasil penelitian ini sejalan dengan penelitian yang dilakukan sebelumnya (7), dimana hasil penetiannya, menunjukkan bahwa terdapat hubungan antara sikap kerja terhadap pemakaian APD dengan nilai $p$-value $=0,001$.

Menurut peneliti, sikap dapat mencerminkan pengetahuan yang diperolehnya dan perbuatan yang dilakukan. Sikap seseorang dari pekerja terhadap penggunaan APD berbanding lurus dengan kesadaran dan pengetahuannya, Semakin baik sikap dan perilakunya maka semakin sadar pekerja tersebut untuk menggunakan APD dalam bekerja, agar dapat menjaga keselamatan dirinya sendiri.

\section{Hubungan Pelatihan K3 terhadap Penggunaan APD}

Hasil penelitian menunjukkan bahwa nilai $p$-value $=0,004$ artinya terdapat hubungan yang signifikan antara pelatihan K3 terhadap penggunaan APD pada Karyawan PT Surya Agrolika Reksa di Sei Basau. Nilai OR= 5,34 (CI95\%; 1,833-15,578) artinya responden yang tidak pernah mengikuti pelatihan K3 9,5 kali lebih beresiko tidak menggunakan APD dibandingkan responden yang pernah mengikuti pelatihan K3. Karena pelatihan K3 sangat berperan penting bagi pekerja untuk menambah pengetahuan tingkat risiko, potensi bahaya ditempat kerja.

Penelitian ini sejalan dengan penelitian yang dilakukan [9], terdapat hubungan antara pelatihan K3 dengan perilaku penggunaan APD dengan nilai $P$-value $=0,002$. Secara teori Pelatihan adalah salah satu metode terbaik yang dapat digunakan untuk mempengaruhi perilaku manusia yang bertujuan dalam pengembangan kebiasaan perilaku bekerja yang aman.Pelatihan mempunyai pengaruh yang besar dan merupakan suatu alat pemotivasi yang kuat dalam keselamatan. Melalui pelatihan seseorang umumnya dapat diberikan tiga hal yaitu pengetahuan, keterampilan dan motivasi.

Berdasarkan hasil penelitian yang dilakukan, sebagian besar responden belum pernah mengikuti pelatihan K3 yaitu sebanyak 35 responden $(53,03 \%)$, dan yang pernah mengikuti pelatihan $\mathrm{K} 3$ terdapat 31 responden $(46,97 \%)$, sehingga bisa diasumsikan bahwapara pekerja yang kurang mengikuti pelatihan terkait dengan penggunaan APD, masih kurang baik pengetahuan dan pemahamannya tentang pentingnya penggunaan APD pada saat bekerja dan para responden atau pekerja juga sudah terbiasa dengan kondisi lalai dalam menggunakan APD.

\section{Hubungan Pengawasan terhadap Penggunaan APD}

Hasil penelitian menunjukkan bahwa nilai $p$-value $=0,015$ artinya terdapat hubungan yang signifikan antara pengawasan terhadap penggunaan APD pada Karyawan PT Surya Agrolika Reksa di Sei Basau. Nilai OR=4,167 (CI95\%; 1,438-12,069) artinya tidak adanya pengawasan 4,1 kali lebih beresiko tidak menggunakan APD dibandingkan dengan adanya pengawasan saat bekerja.Ini menunjukkan bahwa pengawasan terhadap penggunaan APD berhubungan secara 
signifikan, semakin baik pengawasannya maka para pekerja semakin tertib dalam menggunakan APD dalam bekerja.

Menurut [10] menyatakan bahwa, pengawasan merupakan suatu proses untuk mengukur penampilan atau pelaksanaan suatu kegiatan atau suatu peraturan yang telah ditetapkan apakah terlaksana sebagaimana yang telah ditetapkan atau tidak, yang selanjutnya memberikan pengarahanpengarahan kepada pelaksana kegiatan atau peraturan yang telah ditatapkan dapat tercapai.

Dalam [11] menjelaskan bahwa perubahan perilaku individu dimulai dengan tahap kepatuhan, identifikasi, kemudian baru menjadi internalisasi. Mula-mula individu mematuhi tanpa kerelaan melakukan tindakan tersebut dan seringkali karena ingin menghindari hukuman ataupun sanksi, jika dapat mematuhi anjuran tersebut maka biasanya perubahan yang terjadi pada tahap ini sifatnya sementara, artinya bahwa tindakan dilakukan selama masih ada pengawas. Namun pada saat pengawas mengendur perilaku itu pun ditinggalkan lagi.

Menurut hasil penelitian yang dilakukan [12], terdapat hubungan antara pengawasan dengan perilaku penggunaan APD dengan nilai $P$-value 0,005 . Penelitian ini sejalan dengan teori bahwa pengawasan termasuk segala usaha penegakan peraturan yang harus dipatuhi yang merupakan salah satu cara guna meningkatkan keselamatan kerja.

Berbeda dengan dari hasil penelitian saya sebelumnya, di PT PLN Rayon Tembilahan tahun 2017 (13), menunjukkanbahwa tidak terdapat hubungan antara pengawasan dengan penggunan APD pada pekerja teknisi mesin di PT PLN Rayon tembilan tahun 2017 (Pvalue = 0,854 OR 1.429, Cl 95\% = 0.375-5.437) dengan 18 responden menjawab baik dan 17 responden menjawab kurang baik.

Berdasarkan hasil uji statistik dalam penelitian di PT Surya Agrolika Reksa di Sei Basau, diketahui bahwa masih kurangnya pengawasan yang dilakukan, dimana terdapat 42 responden pekerja atau karyawan dari 66 responden yang mengabaikan dalam menggunakan APD, meskipun pengawasan berpengaruh terhadap perilaku seorang pekerja.Pekerja kerap kali tidak mengindahkan atau mematuhi peraturan yang telah ditetapkan karena longgarnya dan kurang baiknya pengawasan yang dilakukan oleh pihak perusahaan. Terbukti bahwa pengawasan terhadap penggunaan APD akan memberikan dampak yang baik dalam bekerja.

\section{UCAPAN TERIMA KASIH}

Terima kasih pada responden, karyawan, staf, K3 officer dan manager K3 PT Surya Agrolika Reksa di Sei Basau. Dan semua pihak-pihak yang sudah berkontribusi dalam proses penelitian ini, termasuk mahasiswa dan rekan dosen yang terlibat langsung dalam penelitian ini.

\section{KESIMPULAN}

Berdasarkan hasil penelitian yang telah dilakukan di PT Surya Agrolika Reksa di Sei. Basau pada Tahun 2017 dapat disimpulkan bahwa terdapat hubungan yang signifikan antara tingkat pendidikan terhadap penggunaan APD pada Karyawan PT Surya Agrolika Reksa di Sei Basau dengan p-value $=0,030$ nilai $\mathrm{POR}=5,0 \quad$ (CI 95\%; 1,28-19,53). Untuk pengetahuan terhadap penggunaan APD, terdapat hubungan yang signifikan antara pengetahuan terhadap penggunaan APD pada Karyawan PT Surya Agrolika Reksa di Sei Basau pada dengan p-value= 0,003 nilai $\mathrm{POR}=6,32$ (CI 95\%;1,97-20,21).

Dari penelitian, diperoleh bahwa karyawan PT Surya Agrolika Reksa di Sei Basau, terdapat hubungan yang signifikan antara sikap kerja terhadap penggunaan APD dengan p-value $=0,000$ nilai $\mathrm{POR}=9,524 \quad$ (CI 95\%; 3,051-29,728). Sementara untuk pelatihan K3 terhadap penggunaan APD pada Karyawan PT Surya Agrolika Reksa di Sei Basau, juga terdapat hubungan yang signifikan antara pelatihan K3 dengan penggunaan APD dengan p-value $=0,004$ nilai $\mathrm{POR}=5,34$ (CI 95\%; 1,833-15,578). Demikian juga antara pengawasan terhadap penggunaan APD pada Karyawan PT Surya Agrolika Reksa di Sei Basau, terdapat hubungan yang signifikan dengan p-value $=0,015$ nilai $\mathrm{OR}=4,167$ (CI 95\%;1,43812,069).

\section{REFERENSI}

[1] Sucipto, Cecep Dani (2014). Keselamatan dan Kesehatan Kerja. Yogyakarta; Gosyen Publishing.

[2] Kurniawati, Dewi (2013). Taktis Memahami Keselamatan dan Kesehatan Kerja. Surakarta : Aksara Sinergi Media.

[3] Ramli, Soehatman. (2010). Sistem Manajemen Keselamatan dan Kesehatan Kerja.Jakarta ; Dian Rakyat.

[4] Notoadmodjo, S (2010). Metodolologi Penelitian Kesehatan. Jakarta: Rineka Cipta

[5] Linggasari (2008). Faktor-faktor yang mempengaruhi perilaku terhadap penggunaan alat pelindung diri di departemen Enginering PT Indah Kiat Pulp \& Paper TBk, Tangerang Tahun 2008.

[6] Notoadmodjo, S (2007). Promosi Kesehatan dan Ilmu Perilaku.Jakarta ; Rineka Cipta

(7) Khamdani, F. (2009). Hubungan Antara Pengetahuan dan Sikap dengan Pemakaian 
Alat Pelindung Diri Pestisida Semprot Pada Petani Di Desa Angkatan Kidul Pati Tahun 2009. Jurusan Ilmu Kesehatan Masyarakat, Fakultas Ilmu Keolahragaan, Universitas Negeri Semarang, i-100.

[8] Azwar. (1999). Sistem dan Prosedur Pemanfaatan Pelayanan Kesehatan Masyarakat. Press : Jakarta.

[9] Rengganis, F. (2012). Faktor Yang Mempengaruhi Perilaku Tenaga Kerja Percetakan Terhadap Penggunaan APD di Bagian Produksi PT. Antar Surya Jaya Surabaya. Vol 1. No. 1

[10] Muninjaya, A.A. Gde (2004), Manajemen Kesehatan, Penerbit Buku Kedokteran EGC, Jakarta.

[11] Wibowo, Arianto. (2010). Faktor - Faktor Yang Berhubungan Dengan Perilaku Penggunaan Alat Pelindung Diri Di Areal Pertambangan PT Antam Tbk unit Bisnis Pertambangan Emas Pongkor kabupaten Bogor.

[12] Bustanul A, \& Susanto A. Faktor - Faktor yang Berhubungan dengan Kepatuhan Pekerja dalam Pemakaian APD di Bagian Coal Yard PT X Unit 3 \& 4 Tahun 2012, \& Masyarakat, F. K. (2013). Jurnal Kesehatan Masyarakat 2013 ,. Vol 2.
[13] Edigan, F., \& Putra, D. P. (2018). Faktor yang Berhubungan dengan Penggunaan APD pada Pekerja Teknisi Mesin di PT PLN Rayon Tembilahan. Saintis. v. 18, n. 1, 73-81.apr. ISSN 2580-7110.

(c) (7) (2) This is an open access article (c) which means that all content is freely available without charge to the user or his/her institution. Jurnal Saintis allows the author(s) to hold the copyright without restriction. The copyright in the text of individual rticles (including research article, opinion articles, and abstracts) is the property of their respective authors distriuted under the terms of the Creative Commons Attribution-ShareAlike 4.0 International License (http://creativecommons.org/licenses/bysa/4.0/) which permits unrestricted use, distribution, and reproduction in any medium. Users are allowed to read, download, copy, distribute, search, or link to full-text articles in this journal without asking by giving appropriate credit, provide a link to the license, and indicate if changes were made. 